University of Minnesota Morris Digital Well

University of Minnesota Morris Digital Well

6-3-2015

\title{
Reading German Girlhood: Louise Tilly and the Agency of Girls in European History
}

Emily Bruce

University of Minnesota - Morris, bruce088@umn.edu

Follow this and additional works at: https://digitalcommons.morris.umn.edu/history

Part of the European History Commons

\section{Recommended Citation}

Bruce, Emily C. "Reading German Girlhood: Louise Tilly and the Agency of Girls in European History." Social Science History 38, no. 1-2 (2014): 97-103.

This Article is brought to you for free and open access by the Faculty and Staff Scholarship at University of Minnesota Morris Digital Well. It has been accepted for inclusion in History Publications by an authorized administrator of University of Minnesota Morris Digital Well. For more information, please contact skulann@morris.umn.edu. 


\section{Emily Bruce}

Ph.D. candidate, Department of History, University of Minnesota

bruce088@umn.edu 


\title{
Reading German Girlhood: Louise Tilly and the Agency of Girls in European History
}

\begin{abstract}
:
This article addresses the legacies of Louise Tilly's work on women and the family in Europe for current studies of girls' agency in history. Using my preliminary analysis of a body of German periodicals written for girls during the late Enlightenment, I propose some methodological possibilities for combining cultural histories of reading with social historical approaches to the roles played by girls and women in European social life. Tilly's focus on the life cycle as an organizing principle and the family economy as a key site of history established the importance of such groups to social historical understandings of the past. Though my study incorporates sources outside the usual bounds of social history, it also depends on the analysis and methods of pioneering feminist social historians such as Louise Tilly.
\end{abstract}

Word count: 3,340 
Though the cultural approaches which guide my investigation of young women and girls as historical actors may seem distant from the methods of which Louise Tilly was a pioneer, I nevertheless see this research following paths of inquiry opened by social history. My analysis of new Enlightenment periodicals published for German girls aims at understanding the experiences of young readers who would not be considered worthy of historical study were it not for scholarship on women's lives and the history of the family advanced by Louise Tilly and her colleagues in feminist social history. Tilly's contributions are part of my work thematically in this sense, but also directly, through the intergenerational transmission of her scholarship by her student, my mentor, Mary Jo Maynes. Moreover, this special section's consideration of Tilly's legacy in terms of her connections with students also resonates with the questions motivating my research on eighteenth- and nineteenth-century German periodicals for girls. That is, there is a parallel between the generations of scholars represented here and my interest in teaching and learning as historical phenomena. These periodicals provoke questions about class and literacy, reading and agency, didacticism and autonomy, in ways that both depend upon and, I hope, extend earlier scholarship on the social history of women. After a discussion of Tilly's work as it has informed my historical understanding, the second part of this essay elaborates on that influence through the example of my current research into the history of girls' reading.

While always acknowledging the parameters of a particular inquiry, Tilly demonstrated a deep conviction in the potential of social history. In a piece on "History as Exploration and Discovery," she writes that history, with

its insistence on identifying empirically within the limits of the sources the facts to be explained, its willingness to discuss the 'how' of building accounts of events, institutions, or the trajectories of lives in the past and the ways historians go about interpreting or analyzing them, provides a more stimulating medium for the message than memorization of facts. (Tilly 1995: 116-117) 
In her presidential address to the American Historical Association, Tilly (1994: 2) explains, "the social history I envision...posits an interdependence of structure and action — human agents produce structures, intentionally or not, even as structures facilitate or constrain human action." This dualism frames my interpretation of girls' agency in European history, within structures of class and gender.

Though the reading girls at the heart of this research are members of a relatively elite class whose historiographical primacy Tilly's work helped to decenter, my emphasis on girlhood is undeniably influenced by her attention to the family as a site of history. Her work with Joan Scott, which emphasizes the relationship of women to their families of origin rather than merely "families of procreation" is particularly useful to understanding the relational locations of these girls (Scott and Tilly 1975: 40). Brother-sister ties, obedience to parents, and shared family spaces are all major themes in German periodicals of the Enlightenment, just as "membership in a family continued to define the work roles and relationships of parents and children" analyzed by Scott and Tilly (1987: 232). The pathbreaking contribution of Women, Work, and Family was far from the only such example. Questions about family relations and experiences motivated Tilly's research throughout her career, as in her study of coal miners in nineteenth-century France (1985), which places family at the center of the history of capitalism and labor. Or consider a volume edited with John Gillis and David Levine, The European Experience of Declining Fertility (1992), which insists that family dynamics are as significant a feature of modern society as industrialization or urbanization. As Tilly and Miriam Cohen write in an essay published in Social Science History on the state of the field, family history "has forced us to reevaluate our everyday assumptions about the contemporary family in light of newer understanding of the past" (1982: 156). Instead of a unifying theory, Tilly and Cohen call for 
'thoughtful 'applied' family history, which can illuminate the way family links affect people's participation in the public sphere, and in turn, the way public sphere change impinges on family" (164).

Just as Tilly's work recognizes the family as a key site of history, her contributions to women's history have helped us understand how women matter to social change. In a survey of gender history, Tilly called for more of "the best women's history," which "endeavors to relate those lives to other historical themes, such as the power of ideas or the forces of structural change" (1989: 447). Referring specifically to the example of the French Revolution, she made a powerful claim for investigating women's participation because "the analysis of revolution is the more comprehensive and systematic to the extent that we take alternate outcomes seriously" (459-460). Beyond investigating women as objects of historical study, however, later in her career Tilly joined others in calling for deeper attention to women's agency. Reflecting on the anniversary of Women, Work, and Family, Tilly admitted that "although we drew upon biographies and life histories we did not portray the women as complex actors" (1999: 29). Partial and incomplete views of agency might require looking beyond available evidence about working-class women; in my case, it involves broadening the source base of women's history by looking at middle- and upper-class girls' reading education.

In the introduction to an updated edition, Tilly and Scott acknowledge that Women, Work, and Family did not encompass the constitution of class cultures or subjectivities. They indicate a direction for future research in those areas. Tilly championed historical studies which made connections between women's lives and class formation, calling for more attention to the intersections of gender and economic structures in a later review essay of gender and women's history (1989). Building from Tilly and Scott's finding that “women's position in the life cycle 
mattered" (Tilly and Scott 1987: 3), I suggest that attention to childhood as a formative period provides a means to investigate the formation of class-based subjectivities. Tilly and Scott used the life course as an organizing principle, but age itself was not a critically examined category in their work. Nevertheless, in deconstructing the binaries that had been drawn between "family and work, tradition and modernity, dependency and autonomy, women and men," Tilly and Scott's book opened up the possibility to consider girls' reading practices in the same breath as major social change in modern Europe (4-5). This has supported my research, which incorporates questions about subjectivity into debates of longstanding interest to social theorists by examining girls' literacy practices through the texts they read.

The usefulness or even legitimacy of a particular kind of source for social science history, such as these girls' periodicals, is not a new problem. For example, a special section of this journal in 1992 addressed the potential and the challenge of incorporating narratives in social science history research. In his introduction to this section, William Sewell notes the resistance of scholars committed to quantitative precision to sources that seemed incomplete records of a few lives rather than the social structures affecting large groups. But he also posits some benefits of moving away from "epistemological purity" with the incorporation of new sources and new research agendas (Sewell 1992: 484). George Steinmetz argues that narratives are not mere secondary sources of anecdotal evidence about quantifiable social history, but rather that "the elaboration of coherent narratives about individual and collective history" is a constitutive component of working-class formation (1992: 489). He demonstrates the possibilities of analysis that combines the cultural aspects of stories people tell about themselves with the study of collective narratives or discourses that shape the social purpose of those stories. Similarly, my 
interest in girls' reading in the Enlightenment is concerned with both the literary or ideological content of the texts and their possible social uses in young women's education.

\section{Louise Tilly's Legacy: One Example ${ }^{\mathrm{i}}$}

In 1802, the first volume of a series called the Encyclopedia for Female Youth (Encyklopädie für die weibliche Jugend) was published in Prague. It begins with a preface that offers a familiar invocation of future motherhood as a reason to educate girls. The author, Antonia Wutka, was remarkable as a woman positioning herself in the pedagogical debates of the Enlightenment, and historians might choose to examine the 44-page forward for an intellectual history of education.

But another way into this text is through its first scene, written in dialogue. Emilie, twelve years old, bursts into the room to find her friend Friderike, also twelve, in dramatic distress. Friderike says that she does not want to read anymore or study anymore; she wants to throw all her books and maps into the fire, and, if it were possible, her schoolmaster, too. Friderike has overheard two men describing her as a "plague of society," who should be left uneducated. Emilie's solution is to form a schooling society ("Unterrichtgesellschaft") with several of their other young friends and Emilie's "teacher, friend, and dear second mother," Auguste, as their leader (Wutka 1802: 4-9). The rest of the volume portrays their lessons: reading aloud to each other from Bible stories and classical myths and asking questions of their teacher.

The religious moralizing and cultivation of separate spheres that constitutes their lessons was not so radical. But the story itself, which is peopled with bright, lively characters and unfolds with small moments of drama, may have offered contradictory opportunities to its young readership in the late Enlightenment. In its rejection of the unnamed men's judgment, this story, ideal for reading aloud or acting out, suggests the importance of girls' own choices and 
community formation. Furthermore, Wutka deploys maternalism to somewhat different purposes than other promotions of woman as mother. I suggest that despite the didactic nature of most publishing for girls during this period, many such contradictions and ambivalences about girls' learning remain to be explored in this new genre.

Most of the publications surveyed in this study were written from the 1780 s through the first decade of the nineteenth century. Different periodicals held varying circulation numbers, often lower in the early years of publication. Paul Nitsch, editor of For German Girls (Für teutsche Mädchen 1781-1782), wrote "with prophetic spirit" that he would like to begin with at least a couple hundred "admirable girls" as readers (Göbels 1986: 28). Even though this publication was short-lived in its original run, it was popular enough to be collected and reprinted by the printer Harpeter some years later.

The intended readership was primarily older "girls," that is, unmarried female youth at a liminal stage, though some sources were aimed at younger children. In fact, age is one of the most obvious boundaries of publishers' intended audience that was permeable in practice. This can be seen in the subscribers' list published in the Lower Saxony Weekly for Children (Niedersächsisches Wochenblatt für Kinder) in its 1781 and 1783 editions. Families of four or five children are all listed by name, spanning enough years to imply that youth may have read before or beyond the age of intended audience.

Parsing actual readership is the first challenge to using these periodicals as part of a social history of girlhood. My analysis seeks to bring together social historical concerns about practice with hermeneutic readings which attend to subjectivity. The texts themselves suggest some ways in which girls' reading practices were scripted by gender, as authors negotiated various questions: What should be the most important affective relationship in a young woman's 
life — female friendship, sibling love, or motherhood and marriage? If girls must be readers, could they be figured as rational, thinking individuals of the Enlightenment, and if not, what were the limitations on that autonomy? The rise of periodicals targeted at girls reveals the cultivation of a particular kind of middle-class subject, formed at the intersections of class, gender, and age. The individual most periodical authors wanted to develop in a girl was devoted to serving others. Both boys and girls were taught to be compassionate and obedient to their families, but the ideal female vocation required disregarding individual personalities and desires - the selfless self. Girls, especially as young children, were supposed to be authentic and unaffected, to enjoy the freedom and pleasures of a protected childhood. But at the same time, it was the purpose of reading education to raise bourgeois subjects who would be socially useful. Pedagogues tried to resolve this dual mission by investing in the entertainment value of their moral tales.

Even the most frivolous periodicals usually included fairly heavy-handed introductions establishing their ideological interest in girls' reading, demonstrating how similar discourses about gender were mobilized for cross-purposes. For example, both the Encylopädie mentioned earlier and Für Deutschlands edle Töchter (1801) start from the position of girl as essentialized future mother. But the latter book uses this rhetoric to constrict women's intellectual opportunities, writing that "most scientific concepts are redundant for [women]. Their purpose is the domestic sphere...therefore they should concentrate on ideas that will cultivate their characters through the principles of a sound morality...learn through knowledge of humankind to manage their children (and perhaps even their husbands)" (1801: ii-iv). By contrast, Wutka (1802: iii) uses this as a critique of Enlightenment philosophy and pedagogy that excluded women, in which "one half of humankind, my sex, is only occasionally included as an 
afterthought, but never attended to as the principal thing; and — there lies the error! —oh! for women, the responsibilities of motherhood continue endlessly!" Her perspective as a rare woman writer in this genre clearly shapes her aims. Still other texts, such as Für teutsche Mädchen, use their prefatory remarks to discuss the balance between pleasure and learning they hope to achieve in their writings in order to attract young female readers.

Yet it is not just the authors' explicit articulations of their pedagogical goals that may contribute to our understanding of girlhood during the Enlightenment. The diverse forms of these periodicals highlight the different ways girl readers might have approached them. Some magazines featured serialized stories — were these followed eagerly from the beginning or picked up mid-narrative? How did periodicals attempt to build loyalty among their readership? In the mixed form of most texts, it is easy to see how readers might pick and choose a poem to reread here, an essay to skim there, or a play to perform. William St. Clair (2004: 5) has suggested other ways of understanding past readership, arguing that even though they were not independent of what they read, readers were free "to skip, to argue, to resist, to read against the grain...to misunderstand... to disagree but to continue reading, to stop reading at any time." However exciting this list of potential relationships between reader and text, how can we see girls exercising this kind of agency while reading, particularly from a distance of two hundred years? Without reducing social life to texts, there remain ways to examine the crucial role this reading played in the socialization of girls. Theories of reception and reader-response provide some strategies for an interdisciplinary approach to reading these books in a new way.

A series of questions may be put to any of these texts about the tactics they use to appeal to their audience: What points of behavior do the authors drill? How do drama, humor, and pleasure enter the didactic narratives? What context and allusions do they expect girls to 
understand? Reading is always an interpretive process with multiple agents who make choices about both the writing and reading of texts. This approach extends to youth readers the work of Louise Rosenblatt's transactional theory of reading and reader-response theory, which sought "to reopen to scrutiny that which has been declared inscrutable, illegitimate or trivial" (Freund 1987: 5). Feminist reading theorists Catherine Lutz and Jane Collins (1993: 218) have suggested that women's reading may be viewed "as an interpretive act and, more than that, as a social, even political, act," when the choice to read is wrested from other responsibilities or expectations. Yet there are obvious limits to the extent we may understand girls' self-formation through these texts alone. Imagining possible ways in which young people may have read the periodicals should be put in conversation with empirical evidence from subscription lists, personal narratives, and other records, though this union of epistemologies may be at first uneasy.

Just as Tilly's research urged us not "to mistake the historical for the natural" (Gillis et al. 1992: 2), and to bring family dynamics and women's experiences to the center of social history, this project seeks to ensure that diverse historical experiences of growing up are not taken for granted. Critical to observing the ambivalences and contradictions of writing for girls in the Enlightenment is not the inconsistencies, but rather the potential such contradictions offered girls to exercise agency, make choices, and interpret their literary and living worlds. Closer analysis of these sources may lead to conclusions about later trends in children's books, or the depiction of peer relationships in eighteenth-century German literature. However, a deeper goal is to connect new, creative ways of understanding literature with the insights of social history evident in Tilly's scholarship, allowing a better understanding of the real girls reading such stories. 


\section{Notes}

For comments on earlier versions of this essay, I thank the Workshop on the Comparative History of Women, Gender, and Sexuality at the University of Minnesota; Miriam Cohen, Mary Jo Maynes, Qin Fang, Ann Waltner, Chip Bruce, and Susan Porter Bruce.

\footnotetext{
${ }^{\mathrm{i}}$ My introduction to this body of sources was supported by a special research grant at the University of Minnesota, the Graduate Research Partnership Program. This award specifically fosters scholarly relationships between mentors and advisees, supporting research that lies at the intersection of a professor and graduate student's interests. A joint application with my advisor, Mary Jo Maynes, allowed a collaboration of the sort that is somewhat unusual in the solitary discipline of history and funded my travel to Germany to examine these rare texts. Thus, my ability to pursue this research is directly linked to the history of intellectual relationships such as Louise Tilly's with her students, as discussed in this section.
} 


\section{References}

Benzler, Johann Lorenz, ed. (1779-1783) Niedersächsisches Wochenblatt für Kinder. Bremen.

Freund, Elizabeth. 1987. The Return of the Reader: Reader-Response Criticism. London: New Accents.

(1801) Für Deutschlands edle Töchter. Leipzig: Johann Gottfried.

Für teutsche Mädchen: Eine Wochenschrift. Dresden: H. W. Harpeter, 1781.

Gillis, John R., Louise A. Tilly, and David Levine, eds. 1992. The European Experience of Declining Fertility, 1850-1970. Cambridge, MA: Blackwell.

Göbels, Hubert. 1986. Zeitschriften für die deutsche Jugend: Eine Chonographie 1772-1960. Dortmund: Harenberg Kommunikation.

Lutz, Catherine and Jane Collins. 1993. Reading National Geographic. Chicago: University of Chicago Press.

Maynes, Mary Jo, Birgitte Søland, and Christina Benninghaus. 2005. Secret Gardens, Satanic Mills: Placing Girls in European History, 1750-1960. Bloomington, IN: Indiana University Press.

Moustier, Karl Albert de. (1803-1804) Griechische und römische Mythen: in Briefen an Emilie. Dresden: Heinrich Gerlach.

Rosenblatt, Louise. (1978) The Reader, the Text, the Poem: The Transactional Theory of the Literary Work. Carbondale: Southern Illinois University Press.

Scott, Joan W. and Louise A. Tilly. (1975) “Women's work and the family in nineteenth-century Europe.” Comparative Studies in Society and History 17: 36-64.

Sewell, William. (1992) "Introduction: narratives and social identities." Social Science History. $479-488$. 
Steinmetz, George (1992) "Reflections on the Role of Social Narratives in Working-Class Formation: Narrative Theory in the Social Sciences.” Social Science History. 489-516. St. Clair, William. (2004) The Reading Nation in the Romantic Period. Cambridge: Cambridge University Press.

Tilly, Louise A. and Joan W. Scott. (1987 [1978]) Women, Work, and Family. New York: Meuthen.

Tilly, Louise A. and Patricia Gurin. (1990) Women, Politics, and Change. New York: Russell Sage Foundation.

Tilly, Louise A. (1985) "Coping with company paternalism: Family strategies of coal miners in nineteenth-century France." Theory and Society 14 (4):403-417.

_. (1989) "Gender, women's history, and social history." Social Science History 13 (4):439-462.

—_. (1995) "History as exploration and discovery." Journal of Social History 29:115-118.

__ (1999) "History/women’s history: Then/now." Journal of Women’s History 11 (3):2730. Wutka, Antonia. (1802) Encyklopädie für die weibliche Jugend. Prague: Caspar Widtmann. 